\title{
Present Situation and Development of Service Trade for Advanced Passenger Car in Xi'an
}

\author{
Jianbo Cao*, Qi Ding \\ Faculty of Science, Xi'an Aeronautical University, Xi'an, China \\ Email: *caojb886@163.com
}

How to cite this paper: Cao, J.B. and Ding, Q. (2019) Present Situation and Development of Service Trade for Advanced Passenger Car in Xi'an. Modern Economy, 10, 1090-1094.

https://doi.org/10.4236/me.2019.104073

Received: February 27, 2019

Accepted: April 6, 2019

Published: April 9, 2019

Copyright $\odot 2019$ by author(s) and Scientific Research Publishing Inc. This work is licensed under the Creative Commons Attribution International License (CC BY 4.0).

http://creativecommons.org/licenses/by/4.0/

(c) (i) Open Access

\begin{abstract}
Development of center-western China was ranked as a very important position by the Chinese government. As one of the most important industries, development of automobile will promote auto-maintain and repair trade in China. Xi'an, a center city in north western, carries out frequently commerce with other areas, progresses rapidly transportation and travel, and increases gradually quantity of various import and homemade vehicles. In Xi'an city, auto-workshops mainly repair small cars at present. There are no special dealers for passenger car. Therefore in Xi'an local, creating some standard dealers that can fix advanced passenger cars and selling auto-parts will have a wide prospect.
\end{abstract}

\section{Keywords}

Advanced Passenger Car, Auto-Maintain and Repair, Present Situation and Development

\section{Introduction}

Many factories have a long experience with repairing various vehicles in Xi'an. They also have some professional contingent. Named passenger car maintain and repair enterprises were developed in a planned way beginning at end of "ninth five" or at "tenth five" in Xi'an. Before that time, administration of the auto-maintain and repair enterprises was not concentration. Supply source of the vehicles was dispersion. In recent two years, quantities and transport of the passenger cars have been grown with 15.8 percent and 17.1 percent, respectively, in the light of statistical data [1] [2]. Their growth rate exceeds greatly the rate of the auto-maintain and repair enterprises increase simultaneously. Most businesses were taken by privately owned workshops. There are 50,000 - 100,000 vehicles to repair every year, where almost 40 percents are large-sized or middle-sized passenger cars and small cars. About 2.5 million yuan RMB profits will 
be available by an enterprise according to repairing or refitting 2000 - 2500 cars every year [3] [4]. New service center, consequently, will be an enterprise that invests limited funds and repays highly and rapidly. There will be greatly economical and social benefits on it.

\section{Operating Tactics}

1) There exist many national preferential policies in the tenth five years plan to north-western China. Those can be made full use by us. We must seek a new way that is both limited investment and much repay, and contribute to Xi'an economy.

2) There exist many qualified scientists and technicians in Xi'an area, who can be invited to the center. By doing this, we will satisfy the ability of research, test and examination and higher technological level for the auto refitting and repairing.

3) Seizing the opportunity is the meaning of possessing market. To forecast market, open up and develop market, satisfy market, service markets are essential aim of the enterprises. The purpose of the operating organization, quality management as well as maintain and repair is just for the market and customers. Specially in the field of refitting vehicles and repairing various small cars, more wide and careful business and too much work have to do. Thus we must change essentially our sense of operation and administration so that adopt market necessary that is varying and growing continually. Therefore, New center should be setting up a special service department and a fast repairing system. We must treat market as a guide and carry out an idea that not only for the repair of cars, but also for the sale of the various auto parts.

\section{Business Scope and Scale}

\subsection{Business Scope}

The new center can refit and repair intermediate and advanced passenger cars, repair, maintain and performance examine various type cars, sell or whole sell parts, engine oil, paint and maintenance products of the various type car.

\subsection{Business Scale}

It will be not less than 3 million yuan RMB If we refit and repair about 1000 large-sized or middle-sized passenger cars every year, where heavy repair 100 cars, middle repair 300 cars and light repair 600 cars, refit or repair about 1300 other type cars every year, where heavy repair 200 cars, middle repair 300 cars and light repair 800 cars, and wholesale or sale of parts, engine oil, paint and maintenance products of the cars.

\section{Investment Budget and Source of the Funds}

\subsection{Investment Budget}

This project will be invested estimably 4.85 million yuan RMB.

1) Investment for repairing equipment will be about 2.3 million yuan RMB. 
2) Investment for the shops, offices and for transforming parking lots will be about 650 thousand yuan RMB.

3) Investment for the training courses will be about 200 thousand yuan RMB.

4) Circulating funds will be about 1.7 million yuan RMB.

\subsection{Source of the Funds}

1) The funds for the training and transforming will be raised by new center.

2) About 50 percent for the equipment will be gotten from bank loan.

3) The circulating funds will be fully gotten from bank loan.

\section{Choice of the Repair and Test Equipment}

To repair cars in the omnibearing and diversifying way, enhance technique and quality level, satisfy market necessaries, new center must purchase a complete set of repair and test equipment.

\section{Source of Sites, Water and Necessary Accessories}

\subsection{Sites (Table 1)}

Table 1. New center need sites of about 4000 square meters for working use.

\begin{tabular}{ccc}
\hline Number & site & quantity $\left(\mathrm{m}^{2}\right)$ \\
\hline 1 & repair shop & 400 \\
2 & body shop & 300 \\
3 & painting shop & 300 \\
4 & machining shop & 100 \\
5 & electrician room & 50 \\
6 & warehouse & 200 \\
7 & office & 200 \\
8 & reception and sales department & 200 \\
\hline
\end{tabular}

\subsection{Water}

New center will need 6 thousand tons of water per month from Xi'an City Waterworks.

\subsection{Power}

New center will need 6 lines power and 560 KVA capacities of the power distribution transformer from Xi'an City Power Department.

\subsection{Gas}

Oxygen, acetylene and carbon-dioxide can be obtained in Xi'an local.

\section{Quantity, Component and Source of Administrative Personnel (Tables 2-4)}

Income every year: 
$2800+2700+1800+600+360+480=8740$ thousand or 8.74 yuan RMB

where amount of 40 percent is material cost, amount of 15 percent is personnel salary, and amount of 20 percent is for tax and other use.

Cost: $8740 \times 80 \%=6992$ thousand or 6.992 million yuan RMB.

Profit every year: $8740-6992=1748$ thousand or 1.748 million yuan RMB.

If sales department can whole sell or sell auto parts, engine oil, paint and maintenance products about 3.5 million yuan RMB every year, the profit for this item will be $3500 \times 15 \%=525$ thousand yuan RMB according to $15 \%$ profit every year.

Total profit every year: $1748+525=2273$ thousand or 2.273 million yuan RMB. Total gross income every year: $3500+7300+1440=12,240$ thousand or 12.24 million yuan RMB. Total tax every year: 1998 thousand or 1.998 million yuan RMB. This project will repay the investment amount of 4.85 million yuan RMB after operating two years and one month.

Equilibrium diagram of curves for the profit and loss. A result of the statistics shows that we will start to profit while amount of 360 cars can be obtained by every year showing in Figure 1.

In the light of above reasons, we must seize the opportunity and find the support of the relative department of government. We have to do something to not only supply the market, but also get considerable economic benefits. We must achieve success and win honor.

Table 2. Calculable economic benefits are shown in follow table by supposing 1000 large-sized and middle-sized passenger cars can be refitted or repaired every year.

\begin{tabular}{cccc}
\hline category & amount (cars/year) & unit price (yuan/car) & total (thousand yuan) \\
\hline heavy repair & 100 & 28,000 & 2800 \\
middle repair & 200 & 9000 & 2700 \\
light repair & 300 & 3000 & 1800 \\
\hline
\end{tabular}

Table 3. Calculable economic benefits are shown in follow table by supposing 1300 various type. Small cars can be refitted or repaired every year.

\begin{tabular}{cccc}
\hline category & amount (cars/year) & unit price (yuan/car) & total (thousand yuan) \\
\hline heavy repair & 200 & 3000 & 600 \\
middle repair & 300 & 1200 & 360 \\
light repair & 600 & 600 & 480 \\
\hline
\end{tabular}

Table 4. Car/category and profit per year.

\begin{tabular}{cccccc}
\hline car/category & $\begin{array}{c}\text { amount } \\
\text { (cars/year) }\end{array}$ & $\begin{array}{c}\text { gross income } \\
\text { (thousand yuan) }\end{array}$ & $\begin{array}{c}\text { Cost (thousand } \\
\text { yuan) }\end{array}$ & $\begin{array}{c}\text { tax (thousand } \\
\text { yuan) }\end{array}$ & $\begin{array}{c}\text { profit (thousand } \\
\text { yuan) }\end{array}$ \\
\hline passenger car & 1000 & 7300 & 4380 & 1460 & 1460 \\
$\begin{array}{c}\text { various type cars } \\
\text { profit/year }\end{array}$ & 1300 & 1440 & 864 & 288 & 288 \\
\hline
\end{tabular}




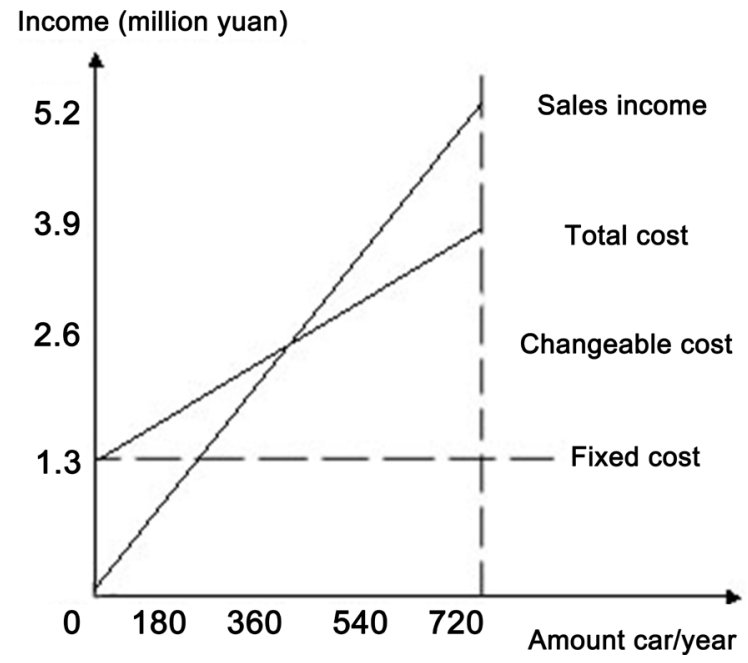

Figure 1. Income per year of the amount cars.

\section{Conclusion}

The conditions of building a service center for advanced passenger car have been satisfied. New service center will be an enterprise that invests limited funds and repays highly and rapidly and will contribute to Xi'an economy.

\section{Conflicts of Interest}

The authors declare no conflicts of interest regarding the publication of this paper.

\section{References}

[1] Rauh, J. (2003) Virtual Development of Ride and Handling Characteristics for Advanced Passenger Cars. Vehicle System Dynamics, 40, 135-155.

https://doi.org/10.1076/vesd.40.1.135.15876

[2] Dickmanns, E.D., Behringer, R., Dickmanns, D., et al. (1994) The Seeing Passenger car 'VaMoRs-P'. Proceedings of the Intelligent Vehicles'94 Symposium, Paris, 24-26 October 1994, 68-73. https://doi.org/10.1109/IVS.1994.639472

[3] Ehsani, M., Gao, Y. and Butler, K.L. (1999) Application of Electrically Peaking Hybrid (ELPH) Propulsion System to a Full-Size Passenger Car with Simulated Design Verification. IEEE Transactions on Vehicular Technology, 48, 1779-1787. https://doi.org/10.1109/25.806770

[4] Ryan, L., Ferreira, S. and Convery, F. (2009) The Impact of Fiscal and Other Measures on New Passenger Car Sales and CO Emissions Intensity: Evidence from Europe. Energy Economics, 31, 365-374. https://doi.org/10.1016/j.eneco.2008.11.011 